\title{
An ethical dilemma in the learning disability services: too much money
}

\author{
Helen Matthews, Sheila Hollins, Jeanette Smith and Gwen Adshead
}

\begin{abstract}
Learning disabillty services care for the needs of patients whose autonomy of thought and action is impaired by processes that often cannot be reversed. Their autonomy may also be limited by external influences such as carers' attiludes, both positive and negative. Others may therefore find themselves making decisions for such patients. The case presented in this paper Ulustrates how these factors can condemn a wealthy woman to a life of relative poverty, lacking in pleasures she could so easily afford, because she lacks competence in some areas of decision making. A possible solution is proposed.
\end{abstract}

\section{Case history (by Matthews 8 Hollins)}

Mary is a woman in her late 30 s living in a hospital 'bungalow' with 23 other adults who have learning disabilities. She was admitted at the age of 18 following the death of her mother 20 years ago. At the same time Mary inherited the family country estate. The last estimate of her personal wealth was in excess of $£ 1,000,000$. She pays the Court of Protection to administer her financial affairs. Her sole surviving relatives, and therefore also her heirs, are two first cousins who visit once a year and send occasional cards and gifts. Her dally life has remained remarkably constant for many years. She shares a bedroom with a quadriplegic woman in her late 20 s with profound learning disability, poor sight and hearing and no speech. Mary washes and dresses herself but has to be prompted with personal hygiene. As a long-stay patient in the hospital, Mary is well known to staff and other residents. However, over the past year she has spent very little time in the bungalow's communal areas as new people have moved in following the closure of another bungalow. They all have profound learning disabilities, are wheelchair users, make loud incomprehensible noises, occasionally injure themselves and many have seizures. Mary seems rather frightened by them. Some of the staff have also changed and the familiar staff remaining are preoccupied with meeting the physical needs of the more disabled residents. It therefore appears that Mary's social world has changed for the worse over the past year.

Mary does not usually carry any money as staff manage her day to day needs. For larger sums such as holidays a requisition is made to a hospital manager with accompanying information. He in turn liaises with the Court of Protection. Mary has a key worker in the bungalow and another in the day centre. Twice in the past two years she has attended an Individual Programme Planning Review (IPPR). Tangible benefits of these reviews have been getting spectacles for watching television, having her hair cut short and not having to go swimming. She is on the waiting list for an advocate to be allocated to her and, as with other residents, her 'resettlement profile' has been constructed by the hospital's resettlement officer. It has been suggested that Mary could buy her own property and share it with other people with learning difficulties with whom she gets on but there are doubts about whether this is legally possible. Most staff are fully aware of Mary's wealth and feelings of envy are sometimes apparent during clinical discussions.

When it comes to considering this patient's financial affairs the role of her doctors is not clear. Mary is an in-patient for whom a consultant psychiatrist has clinical responsibility. Ten years ago, her consultants were still expected to approve the use of an individual patient's monies, as their role extended to all aspects of an individual's life. However, the doctor's role in learning disability services has been criticised for being too paternalistic and is no longer assumed to be as extensive as in the past.

This account will probably sadden but not surprise many readers. Mary, like so many people with learning disabilities, has had few opportunities to enjoy an ordinary life. We are sure she does not 'like' most of the people she currently finds herself living with and consequently the quality of her current life style appears to be unnecessarily poor. The major barrier 
to service development is usually assumed to be financial. However this lady, at a conservative estimate, could have an annual income of $£ 50,000$. Evidently there are forces and structures within the present system which prevent Mary from spending her own money, and purchasing a life style for herself which would give her more pleasure.

Finally, as people employed to care, how do we cope with caring for people rich beyond our wildest dreams? We are used to feeling sorry for our patients, not envious. Perhaps Mary would fare better with a lot less money. By treating everyone the same, we could be condemning people into a disability underclass characterised by poverty: financial poverty but also poverty of opportunity, poverty of emotional experience and lack of control in their own lives. By possibly failing to allow people to spend their wealth because of a perceived lack of equality with other disabled people, we may be imposing socialist ideals on those unable to choose for themselves. Consequently, they may be forced to settle for living conditions we ourselves would not tolerate. We believe the present system should be challenged, but who should be challenged and by whom?

\section{Commentary (by Smith \&2 Adshead)}

When considering whether doctors have any role at all in discussions about the disposal of patients' finances, it may be helpful to distinguish between two models of health care: the 'curing' model, and the 'living with disability' model. Each presents different perspectives of the scope of clinical responsibility. The 'disability' model, employed most commonly in learning disability services, implies a more holistic approach than a traditional 'curing' model. Thus all aspects of the patient's life may be concerned in clinical decision making. Health care professionals may be responsible for financlal issues if these affect the patient's overall quality of life, and the patient is not competent to make financial decisions him or herself. The chief clinical task may then be to determine the scope of the patient's competence in decision making. Decisions concerning finances can then be made involving clinicians as well as lawyers and managers, to ensure that the patient's needs are adequately addressed.

This model does carry with it the risk of usurpation of judgement from patient to doctor; a process that may be called paternalistic. But paternalism may be 'strong' or 'weak', depending on the competence of the patient to make judgements. Although 'strong' paternalism, where the patient is fully competent is undesirable, 'weak' paternalism may be a necessary part of some types of doctor-patient relationship. Wherever possible, the patient should be part of all decision processes affecting him or her. But sometimes, health care professionals will have to make judgements as to whether the patient is competent to take part in these processes, and if not, may be among the best people to make decisions for the patient.

In general, there should be care policies for the management of residents' financial affairs, where residents are not competent to make financial decisions. Ideally these should offer guidance about how to use individuals' financial resources for their own benefit, and include guidelines about assessment of competence in decision making. For example, it would be helpful to know whether Mary has any concept at all of her wealth, and if so, what contribution she could make to discussions of how it should be spent. It is likely that, although competent to make daily living types of decisions, such as what to eat or wear, Mary is not competent to make more complex decisions, such as future planning for her own care. In particular, Mary is probably not sufficiently competent either to choose those things that will benefit her in the future, or to refuse those things (including advisers) that will be to her detriment. It is therefore important to identify those who should be responsible for making these decisions, and implementing them. To do this may (but need not) involve spending Mary's money. This money is therefore only instrumental to purchasing benefits for Mary; benefits that she would choose herself, if competent.

The problem of managing the financial needs of one who is not fully competent is not dissimilar to that of managing his or her physical needs. The legal implications of this were discussed in the case, re $F$. The question then was who can decide for the incompetent, and on what criteria. In Mary's case, who can decide on financial issues for her, and especially who can be trusted with potential access to $£ 1,000,000$ ? The existing hospital structures and the Court of Protection are designed to prevent exploitation of vulnerable individuals. Key workers may not be sufficiently objective, and their opinions may be influenced by envy, or ignorance of relevant legal issues. They also do not hold legal responsibility for Mary. However, key workers are likely to know the individual best, but may not be able to influence the Court of Protection, or act as true advocates who can challenge management decisions. There is therefore a tension between those who make decisions, but do not know Mary personally, and those who know her but cannot make decisions.

The answer is probably a group; a 'Mary Management Board', including Mary's doctor, key workers, advocate, friend, solicitor, the receiver or visitor from the Court of Protection and in Mary's case a financial adviser. Such a board 
could address Mary's specific needs in a way that is consistent with current policies of care planning; in this case, financial needs assessment and planning. It might be argued that a 'Mary Management Board' is only carrying out tasks that would normally be performed by relatives, but with far more possibilities for self-scrutiny and regulation. Such a group could, on Mary's behalf, test out legally whether it is possible for Mary to purchase care for herself in the private sector, i.e. by purchasing a home and hiring staff for herself.

Such a 'management board', involving a number of different perspectives of Mary and her needs, could overcome the attitudinal, organisational and emotional barriers which may be preventing Mary getting the best care possible. Those who left Mary her money obviously hoped thereby that she should have the most pleasurable and comfortable life available. It is the duty of all Mary's carers to ensure that she gets it.

Mary's case illustrates how the feelings of carers, and the relationship between carers and patients, can be highly influential in determining the quality of that patient's life, and making ethical decisions. Our perspective of our ethical duties towards a patient is likely to be determined by the model of health care espoused, and our view of the clinical relationship, which in turn is affected by our feelings. This is important, as it makes clear that it is often clinician's feelings that drive them into 'unethical' practices. It is therefore relevant to ethical decision making to understand the nature and the quality of clinical relationships; a theme to which we will return later in the series.

\section{References}

re F [1989] I Med LR 58; (Mental patient: sterilisation) [1990] 2 AC 1.

\section{Further reading}

BiCKNELL, D.J.B. (1989) Consent and people with mental handicap. British Medical Journal, 1176-1177.

DEPARTMENT OF HEALTH AND SOCLAL SECURTY (1971) Hospltal Memorandum on Patients' Moneys.

- - (1993) Looking After Your Money in Hospital.

LAW Commssion (1993) Mentally Incapacttated Adults and Dectsion Making: medical treatment and research. A consultation paper. The Law Commission, 37-38 John Street, London WC1N 2BQ

MENCAP (1989) Competency and Consent to Medical Treatment. Report of the Working Party on Legal, Medical and Ethical Issues of Mental Handicap. Mencap.

National Association OF HEALTH Authormtes aND TRUSTS (1992) Other People's Money-guidance on the responstbilities of formal carers in the NHS.

Helen Matthews, Senior Registrar; Shella Hollins, Professor, Head of Division of Psychiatry of Disability, St George's Hospital Medical School, London SW17 ORE; Jeanette Smith, Senior Registrar, Fromeside Clinic, Blackberry Hill, Bristol BS16 1ED and Gwen Adshead, Lecturer, Department of Forensic Psychiatry. Institute of Psychiatry, De Crespigny Park, London SE5 8AF 